\section{IOVEMBAR METIIG}

Nov. 14-16. Biotech USA: The 5th Annual Industry Conference and Exhibition. San Francisco, CA. Info: Biotech USA '88, c/o CMC, 200 Connecticut Ave., Norwalk, CT 06856-4990 Tel: 1-800-243. 3238 ext. 232.

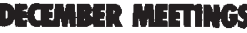

Dec. 5-6. The Third Annual International Bioprocessing Conference. Atlanta, GA. Info: Jan Keaton, Clemson University. Continuing Engineering Education, P. O Drawer 1607, Clemson, SC 29633-1607.

Dec. 5-6. Animal Patent Conference. Ithaca, NY. Info: Prof. William Lesser, Dept. of Agricultural Economics, 309 Warren Hall, Cornell University, Ithaca, NY 14853.

Dec. 5-7. Gas, Oil, and Coal Biotechnology. New Orleans, LA. Info: Susan Robertson, Coordinator, Industrial Education, Institute of Gas Technology, 3424 S. State St., Chicago, IL 60616.

Dec. 9-10. The 1988 Annual Conference of the American Academy of Pain Medicine. Anaheim, CA. Info: Jack Pinsky, MD, Pain Medicine, California College of Medicine, University of California Irvine Medical Center, 101 City Dr. South, Orange, CA 92668-3297.

Dec. 12-13. HPLC of Biopolymers. Iselin, NJ. Info: Janet Cunningham, Barr Enterprises, P. O. Box 279, Walkerville, MD 21793.

Dec. 12-20. Recent Advances in Bio-process Engineering. New Delhi, India. Info: The Secretary, Biochemical Engineering Research Center, Indian Institute of Technology, Delphi, Haus Khas, New Delhi 110016 , India.

Dec. 15. The Coming Profit Opportunities in Biotechnology: A New Assessment. Washington, DC. Info: Ray Goodwin, Consulting Resources Corp., 6 Northbrook Park, Lexington, MA 02173.

Dec. 19-21. Cell Surface Properties and Bacterial Pathogenicity. London, UK. Info: Dr. C. S. Dow, Dept. of Biological Sciences, University of Warwick, Coventry CV4 7AL, England.

\section{MUNT MaTnes}

Jan. 12-15. The Scientific and Clinical Basis of Cancer Biotherapy. Franklin, TN. Info: Veronica Maleckar, The Biological Therapy Institute, Hospital Dr., P. O. Box 1676, Franklin, TN 27065-1676.
Jan. 12-19. Frontiers of NMR in Molecular Biology. Park City, UT. Info: UCLA Symposia, 103 Molecular Biology Institute, Los Angeles, CA 90024-1378.

Jan. 14-19. AAAS Annual Meeting. San Francisco, CA. Info: AAAS Meetings Office, 1333 H St., N. W., Washington, DC 20005.

Jan. 14-20. Glycobiology. Frisco, CO. Info: See for Jan. 12-19.

Jan. 17-22. Protein and Pharmaceutical Engineering. Park City, UT. Info: See for Jan. $12-19$.

Jan. 20-27. New Directions in Biological Control. Frisco, CO. Info: See for Jan. 12 19.

Jan. 21-27. Growth Regulation of CancerII. Keystone, CO. Info: See for Jan. 12 19.

Jan. 21-27. Genetic Mechanisms in Carcinogenesis and Tumor Progression. Keystone, CO. Info: See for Jan. 12-19.

Jan. 21-28. Immunogenicity. Steamboat Springs, CO. Info: See for Jan. 12-19.

Jan. 28-Feb. 3. Transgenic Models in Medicine and Agriculture. Taos, New Mexico. Info: See for Jan. 12-19.

Jan 29-Feb. 3. American Society for Biological Chemistry \& Molecular Biology/ American Society of Cell Biology. San Fransico, CA. Info: American Society of Cell Biology, 9650 Rockville Pike, Bethesda, MD 20814.

\section{FEAUARY MatnIIES}

Feb. 3-8. Early Embryo Development and Paracrine Relationships. Taos, New Mexico. Info: See for Jan. 12-19.

Feb. 4-11. Human Retroviruses. Tamarron, CO. Info: See for Jan. 12-19.

Feb. 5-9. Management and Regulation of New Technology-Biotechnology, Electronic NDA's and Variability in Drug Response. Austin, TX. Info: Salomon Stavchanshy, Division of Pharmaceutics, College of Pharmacy, The University of Texas at Austin, Austin, TX 78712-1074.

Feb. 6-10. The $1989 \mathrm{Miami}$ Bio/Technology Winter Symposium: Advances in Gene Technology: Molecular Neurobiology and Neuropharmacology. Miami, FL. Info: The Miami Bio/Technology Winter Symposium, P. O. Box 016129, Miami, FL 33101-6129.
Feb. 8-10. Clinical Laboratory Molecular Analysis. San Diego, CA. Info: Bonny Mower, Dept. of Academic Affairs, Box 400S, Scripps Clinic and Research Foundation, $10666 \mathrm{~N}$. Torrey Pines Rd., La Jolla, CA 92037.

Feb. 20-27. Defense Molecules. Lake Tahoe, CA. Info: See for Jan. 12-19.

\section{COULEN AND WORKSHOPS}

Dec. 12-13. Modern Methods in the Analysis and Purification of Biopolymers: HPLC and Capillary Electrophoresis. Iselin, NJ. Info: Janet Cunningham, Barr Enterprises, P. O. Box 279, Walkersville, MD. 21793.

Jan, 3-7. Recombinant DNA Methodology. Washington, DC. Info: Roland Nardone, The Center for Advanced Training, The Catholic University of America, Washington, DC. 20064.

Jan. 9-13. Basic Cell and Tissue Culture. Washington, DC. Info: Roland Nardone, The Center for Advanced Training, The Catholic University of America, Washington, DC. 20064.

\section{DXCUINE CHAMCES}

Merck Sharp \& Dohme Research Laboratories (West Point, PA) promoted Charles C. Leighton to senior vice president for medical and regulatory affairs worldwide.

Houston Biotechnology (The Woodlands TX) named David $M$. Leech president and chief executive officer.

TosoHaas (Philadelphia, PA) appointed William $\mathrm{H}$. Staas president.

Human Genome Organization (HUGO) elected Victor A. McKusick of Johns Hopkins University (Baltimore, MD) president of this group of international scientists joined to collaborate on mapping and sequencing the human genome.

Marrow-Tech (Albany, NY) appointed Magdalena G. Eisinger to a newly created position on its scientific advisory board.

Viagene (San Diego, CA) named Gregory D. Phelps president and CEO.

Incell (Milwaukee, WI) announced the appointment of William F. Amon, Jr. as president and CEO.

Immunomedics (Newark, NJ) announced the resignation of George $W$. Masters as president. 